\title{
PERANCANGAN SISTEM INFORMASI PRESENSI MENGGUNAKAN SIDIK JARI UNTUK PEGAWAI NEGERI KABUPATEN KARAWANG
}

\author{
${ }^{1}$ Jajam Haerul Jaman, ${ }^{2}$ Garno \\ ${ }^{1,2}$ Universitas Singaperbangsa Karawang, Teknik Informatika \\ 1)jajam.haerul@yahoo.com ${ }^{2}$ muhammad.garno@staff.unsika.ac.id \\ ${ }^{1,2}$ Jl. H.S. Ronggowaluyo, Telukjambe Timur, Karawang 41361
}

\begin{abstract}
ABSTRAK
Pemerintahan kabupaten karawang untuk mengetahui kedisiplinan pegawainya secara dini yaitu dengan system kontrol kedisiplinan pegawai. Sistem kontrol tersebut yaitu dengan mengontrol absensi, walaupun absensi belum mewakili semua bahwa dengan absensi yang bagus berarti pegawai tersebut etos kerjanya juga bagus, namun setidaknya untuk memulai dari sisi kedisiplinan masuk kerja tepat waktu dan pulang tepat pada waktunya. Program kedisiplinan pegawai dengan menerapkan setiap pegawai masuk kerja harus absensi dengan fingerprint saat datang di pagi hari jam 08:00 dan pulang di sore hari jam 17:00 wib, dan hasil sistem absensi tersebut direport dan dipantau langsung oleh badan kepegawaian kabupaten karawang dengan nama presensi pegawai kabupaten karawang.
\end{abstract}

Kata Kunci: fingerprint, absensi

\section{PENDAhuluan}

Karawang dalam membangun wilayahnya diperlukan sumber daya pemerintahan yang disiplin dengan sistem kepegawaian yang dapat meningkatkan hasil kinerja disetiap sektor dan departemen, untuk dapat mengetahui kedisiplinan pegawainya secara dini yaitu dengan sistem kontrol kedisiplinan pegawai. Sistem kontrol tersebut yaitu dengan mengontrol absensi, walaupun absensi belum mewakili semua bahwa dengan absensi yang bagus berarti pegawai tersebut etos kerjanya juga bagus, namun setidaknya untuk memulai dari sisi kedisiplinan masuk kerja tepat waktu dan pulang tepat pada waktunya. Presensi kepegawaian di kabupaten Karawang ini tentunya harus memiliki sistem yang tersentralisasi, baik dari kepegawaian ditingkat yang paling bawah sampai kepegawaian ditingkat yang paling atas, yaitu dengan sistem yang dapat dipantau dari pusat, artinya dari masing-masing divisi atau departmen dapat terhubung/link kepusat kontrol kepegawaian yang berhubungan dengan pengelolaan gaji dan sumber daya manusia.

Sistem presensi ini dibuat secara privat dan tidak dapat diwakilkan, dan saat ini yang akan digunakan yaitu dengan sidik jari masing-masing pegawai, sistem pemanfaatan sidik jari merupakan satu pemanfaatan yang dapat digunakan untuk salah satunya teknologi presensi. Sistem presensi sidik jari merupakan salah satu teknologi yang dapat digunakan dalam mengidentifikasi seseorang(Leksono et al. 2011), bahkan sidik jari merupakan salah satu teknologi yang cukup handal karena terbukti relative akurat, aman dan nyaman(Ngantung et al. 2014) untuk dipakai, hal ini disebabkan oleh beberapa sifat sidik jari yaitu antara lain; layak, berbeda satu dengan yang lain, tetap, akurat, handal, dan dapat diterima(Apriyanto n.d.2015). Presensi dengan sidik jari merupakan salah satu cara untuk meningkatkan kedisiplinan pegawai pada suatu instansi dengan alat fingerprint yang canggih yang dapat merekam sidik jari seseorang yang dapat menghindari terjadinya korupsi waktu.

\section{LANDASAN TEORI}

A. Teknologi Sidik Jari dan Biometrik

Teknologi biometrika merupakan sebuah teknologi baru yang memiliki fungsi utama untuk mengenali manusia melalui sidik jari, mata, wajah, atau bagian tubuh yang lain(Teknologi et al. 2015). Sistem biometrika sidik jari merupakan sistem autentifikasi berbasis biometrika yang paling banyak digunakan saat ini karena memiliki tingkat akurasi yang tinggi dan mudah diterapkan. Dari hasil penelitian, ditemukan 7 macam pola utama pappilary ridge, antara lain: Loop, Arch, Whorl, Tented Arch, Double Loop, Central Pocked Loop, dan Accidental(Nurhantara 2011).

Sidik jari tentunya memiliki pola, dan pola sidik jari di namakan dermatoglifi, menurut Tina Fajrin dalam jurnal yang berjudul analisis sistem presensi dengan sidik jari siswa smk negeri 2 Karanganyar bahwa menurut Olivier dermatoglifi atau pola sidik jari didefinisikan sebagai gambaran sulur-sulur dermal yang pararel pada jari-jari tangan dan kaki, serta telapak tangan dan telapak kaki. Istilah 
dermatoglifi diperkenalkan pertama kali oleh Cummin dan Midloo pada tahun 1926. Secara anatomis dermatoglifi akan membuat permukaan kasar pada telapak tangan jari tangan, telapak kaki, dan jari kaki yang berfungsi dalam membantu proses memegang atau berpijak sehingga tidak tergelincir. Pembentukan dermatoglifi dimulai dengan proliferasi sel epitel basal epidermis volar pada sekitar minggu ke-10 sampai minggu ke-11 kehamilan. Sel-sel kemudian membentuk lipatan-lipatan dan menjadi rigi episermis. Pada bulan keenam kehamilan pembentukan dermatoglifi berakhir sepenuhnya(Karanganyar 2012).

\section{B. Representasi Citra Sidik Jari}

Sidik jari merupakan salah satu cara identifikasi yang bersifat unik, karena hingga saat ini belum ditemukan adanya kesamaan pola sidik jari antara satu orang dengan orang lain sehingga sidik jari dapat dijadikan sebagai alat untuk mengidentifikasi validitas seseorang(Rozikin \& Purwantini 2014). Secara umum pola sidik jari dapat dinyatakan ke dalam tiga bentuk yaitu : Arch, Loop dan Whorl. Perangkat fingerprint merupakan perangkat yang digunakan untuk mengambil gambar sidik jari, salah satu metode yang paling banyak digunakan saat ini adalah optical scanning. Inti dari scanner optical adalah charge coupled device (CCD) yang merupakan sebuah larik sederhana dari diode peka cahaya yang disebut photosite. Setiap photosite merekam sebuah pixel yang membentuk pola terang dan gelap dari sebuah gambar hasil scan sidik jari seseorang.

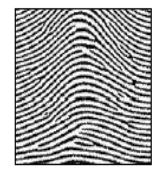

Arch

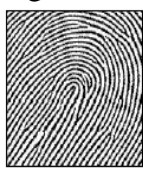

Loop

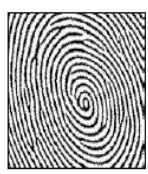

Whorl

Gambar Pola Sidik Jari

Teknik pembacaan sidik jari dengan optical atau optis mempunyai sistem merekam pola sidik jari dengan menggunakan blitz (cahaya). Alat pembaca sidik jari atau fingerprint scanner yang digunakan adalah berupa kamera digital. Lapisan paling atas area untuk meletakkan ujung jari atau permukaan sentuh (scan area). Di bawah scan area, terdapat lampu blitz atau pemancar cahaya yang difungsikan untuk menerangi permukaan ujung jari. Karena sidik jari terkena cahaya maka akan menghasilkan pantulan dari ujung jari yang selanjutnya ditangkap oleh alat penerima. Data tersebut selanjutnya disimpan ke dalam memori(Karangayar 2012).

C. Otentikasi sidik jari

Authentication merupakan aspek menjamin informasi tersebut adalah asli. Dalam journal Teknik POMITS yang berjudul implementasi fungsi kriptografi dan otentikasi sidik jari pada pemungutan suara berbasis elektronik bahwa Otentikasi berarti memberikan bukti terhadap suatu identitas. Teknik otentikasi berbeda-beda tergantung dari tipe sumber otentikasi yang digunakan. Beberapa macam sumber otentikasi yang digunakan dapat digolongkan menjadi dua hal (berdasarkan tujuan otentikasi) yaitu, user -to-host dan host-to-host. Otentikasi dapat dilakukan dengan menyajikan data-data Sesuatu yang menunjukan jati diri (something you are /SYA), sesuatu yang diketahui (something you know / SYK), Sesuatu yang dimiliki (something you have / SYH)(E-voting et al. 2013).

\section{Akuisisi citra sidik jari}

Tahap akuisisi citra adalah tahap yang diawali dengan menangkap/ mengambil gambar sidik jari dengan menggunakan scanner. Citra sidik jari yang diolah adalah citra grayscale dengan 256 tingkat keabuan dan memiliki dimensi 320 x 320 pixel, dengan kerapatan gambar 300 dpi(Candra \& Santi 2008).

\section{E. Konsep dasar fingerprint}

Sistem berbasis fingerprint adalah sistem yang menggunakan karakteristik sidik jari dari manusia untuk autentikasi seperti sistem verifikasi dan identifikasi. Fingerprint adalah gurat-gurat yang terdapat dikulit ujung jari. Fungsinya adalah untuk memberi gaya gesek lebih besaragar jari dapat memegang benda-benda lebih erat. Sidik jari dapat digunakan sebagai sarana pengamanan dalam melakukan akses ke komputer karena sidik jari mempunyai ciri yang unik, setiap manusia memilikinya, dan selalu ada perbedaan antara yang satu dengan yang lain. Hal ini mulai dilakukan pada akhir abad ke19 (Angraini, 2009).

Proses Identifikasi sidik jari akan melalui beberapa tahapan yaitu akuisisi sidik jari, grayscalling, thresholding, thinning dan template matching. untuk bahasa pemrograman dan database 
yang digunakan dalam aplikasi berbasis web menggunakan $p h p$ dan $h t m l$ serta database yang digunakan dengan mysql(Tominanto 2013).

\section{METODOLOGI PENELITIAN}

Metode penelitian dalam perancangan sistem presensi pegawai negeri sipil di Kabupaten Karawang dengan metode rekayasa perangkat lunak system development life cycle dengan model pendekatan prototyping. Model prototyping sendiri memiliki kelebihan dapat digunakan untuk menyambungkan ketidakpahaman pelanggan terutama mengenai hal teknis serta dapat memperjelas sepesifikasi kebutuhan yang diinginkan pelanggan kepada pengembangan perangkat lunak.

\section{A. Analisi Masalah}

Tahapan pengumpulan kebutuhan dilakukan sebagai faktor utama untuk membangun suatu sistem, namun sebelum membangun perlu mengetahui masalah di tempat penelitian, masalah awal dari sistem kerja yang menggunakan model rekap kehadiran yang manual adalah banyaknya kehadiran yang melebihi jam masuk kerja yang telah ditetapkan sebagai peraturan masuk kerja yaitu jam 08:00 wib, karena hanya menggunakan tanda tangan saja sebagai tanda masuk kerja ditiap harinya, artinya jika dibiarkan terus menerus budaya kedisiplinan masuk kerja sudah tidak ada dan juga ketika jam pulang kerja yang seharusnya jam16:00 wib banyak yang disiang hari melakukan dinas luar dan tidak kembali kekantor.

\section{B. Analisi Sistem Berjalan.}

Melakukan analisis sistem yang berjalan bertujuan sebagai dasar perancangan atau perbaikan sistem yang lama yaitu dari kondisi yang masih manual menjadi digital. Berdasarkan hasil observasi yang dilakukan dan wawancara dengan pihak bagian kepegawaian didapatkan alur interaksi pegawai dengan sistem dan petugas dengan sistem yang dapat digambarkan dengan use case sebagai berikut :

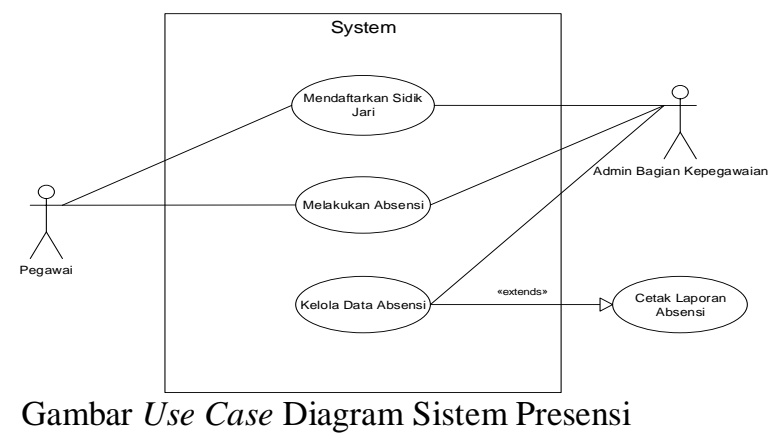

C. Analisi Kebutuhan Fungsional

Analisis kebutuhan fungsional menggambarkan proses kegiatan yang akan diterapkan dalam sistem dan menjelaskan kebutuhan yang diperlukan agar sistem dapat berjalan dengan baik serta sesuai dengan kebutuhan sistem kepegawain. Adapun kebutuhan fungsionalnya dari petugas kepegawaian adalah : mengolah data pegawai, melakukan pendaftaran sidik jari, mengolah jadwal kerja pegawai.

D. Analisi Desain Infrastruktur Jaringan 


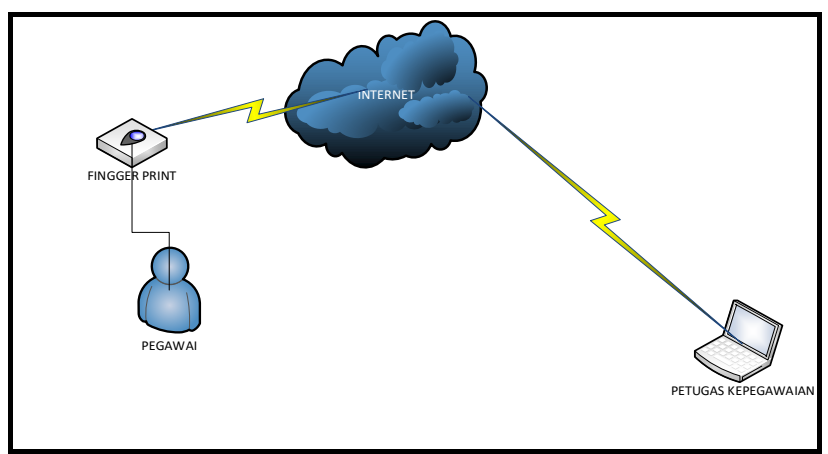

Gambar Infrastruktur Jaringan

Desain infrastruktur jaringan yang akan dibangun yaitu mesin fingerprint terhubung ke komputer yang telah terinstall driver/software fingerprint dan komputer tersebut terhubung ke internet untuk dapat akses ke webserver ditempat yang berbeda. Server yang telah di forward oleh router dengan ip publik yang mana server tersebut tempat desain web berada, atau dapat juga web tersebut di server cloud artinya membangun web dengan membeli hosting dan domain. Terakhir petugas kepegawaian mengakses web tersebut untuk mendapatkan record dari absensi setiap harinya.

\section{E. Tabel Relational}

Pembangunan sistem absensi untuk pegawai Kabupaten Karawang memerlukan data-data yang tergabung dalam tabel, adapun data-data yang dibutuhkan dapat digambarkan dalam tabel relational sebagai berikut;

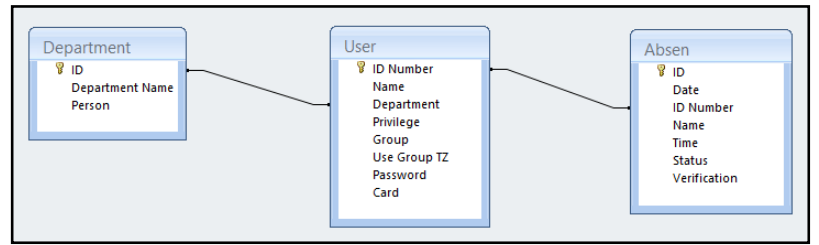

Gambar Desain Tabel Relational

\section{PERANCANGAN}

A. Desain Web Absensi

Interaksi aktor dengan aplikasi pada sistem absensi digambarkan sebagai fitur yang dapat dilakukan dalam pengelolaan data absensi dimana dalam fitur tersebut terdapat menu kelola user, departmen dan pengelolaan laporan

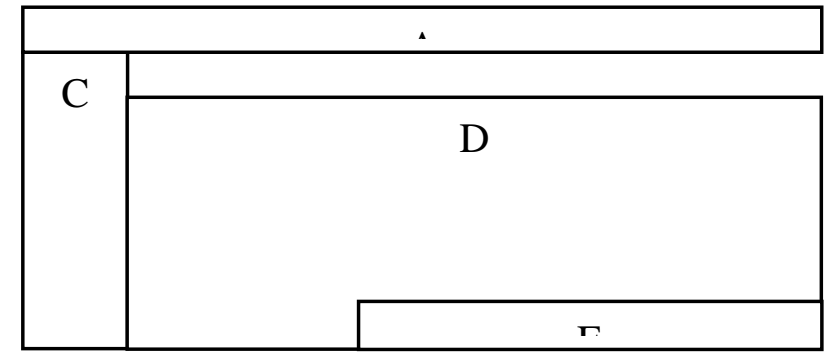

Gambar Perancangan Interface Aplikasi

Ket: $\mathrm{A}=$ Header aplikasi, $\mathrm{B}=$ Title menu yang sedang aktif, $\mathrm{C}=$ Menu aplikasi, $\mathrm{D}=$ Konten menu yang dipilih, E = Footer berupa copyright

\section{B. Login Web Aplikasi}

Pengelolaan data absensi, administrator diharuskan login terlebih dahulu kedalam web dengan memasukan alamat domain web yang terhubung dengan mesin fingerprint didalam browser. 


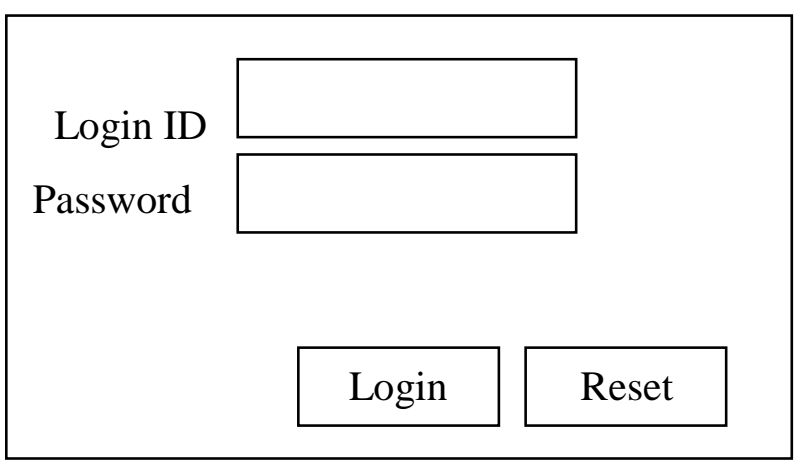

Gambar Desain interface login

Isi form Login ID dan Password sesuai dengan ID yang dimiliki. Apabila ID dan Password tidak sesuai dengan database maka aplikasi akan memberikan pemberitahuan dan administrator harus mengulangi mengisi form. Apabila ID dan Password sesuai dengan database maka administrator akan masuk ke halaman utama web

\section{Managemen Data Pegawai}

Pegawai yang dapat menggunakan absensi fingerprint harus terdaftar dahulu dalam database web kemudian mendaftarkan sidik jari masing-masing di dalam masein fingerprint. Dikarenakan banyaknya pegawai dalam satu instansi, managemen data pegawai pun menjadi salah satu fitur web aplikasi. Berikut use case diagram management data pegawai.

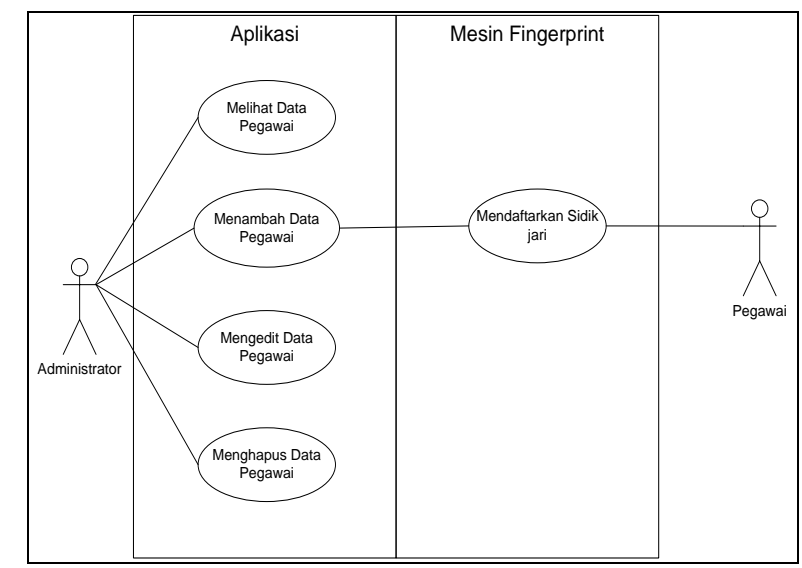

Gambar Use case Managemen Pegawai

D. Melihat Data Pegawai

Dengan mengklik menu User, administrator dapat melihat seluruh pegawai yang terdaftar di mesin fingerprint. Dalam menu ini juga terdapat pilihan sortir data berdasarkan department dan fitur pencarian data berdasarkan ID.

\begin{tabular}{|c|c|c|c|c|c|c|c|}
\hline \multicolumn{8}{|c|}{ User } \\
\hline \multirow{2}{*}{\multicolumn{3}{|c|}{$\begin{array}{l}\text { Srort By Department } \\
\text { Search ID }\end{array}$}} & & & & \multirow{2}{*}{\multicolumn{2}{|c|}{ Search }} \\
\hline & & & & & & & \\
\hline \multirow[t]{2}{*}{$\sqrt{ }$} & Department & ID & Name & Card & Group & Privilege & Action \\
\hline & & & & & & & edit \\
\hline
\end{tabular}

Gambar desain interface melihat data user 
E. Menambah Data Pegawai

Penambahan data pegawai dilakukan di dalam web oleh administrator, dengan mengklik menu Add User. Dalam mengisi data, kolom ID Number dan Name wajib diisi oleh administrator. Kolom ID Number tidak boleh berisi data yang sama dengan ID pegawai lainnya. Apabila seluruh data telah siap, klik tombol Add dan data akan tersimpan di database.

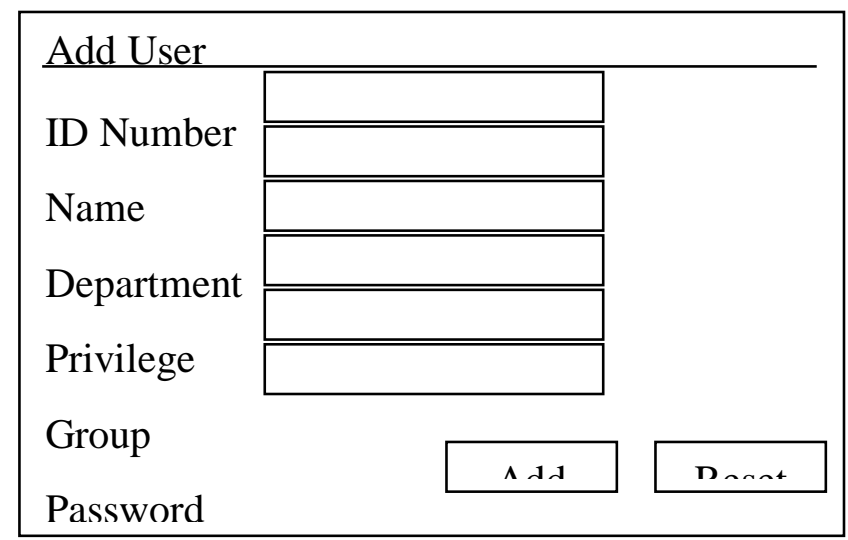

Gambar desain interface tambah data pegawai

\section{F. Cetak Laporan Absensi}

Mencetak laporan absensi dapat dilakukan dalam menu Download. Setelah mengklik menu Download, pilih data pagawai yang akan di cetak. Administrator dapat memilih semua pegawai dengan mengklik ikon cek all di kiri atas. Setelah memilih pegawai, pilih periode data absensi yang akan di cetak. Bila telah siap, klik tombol Download.

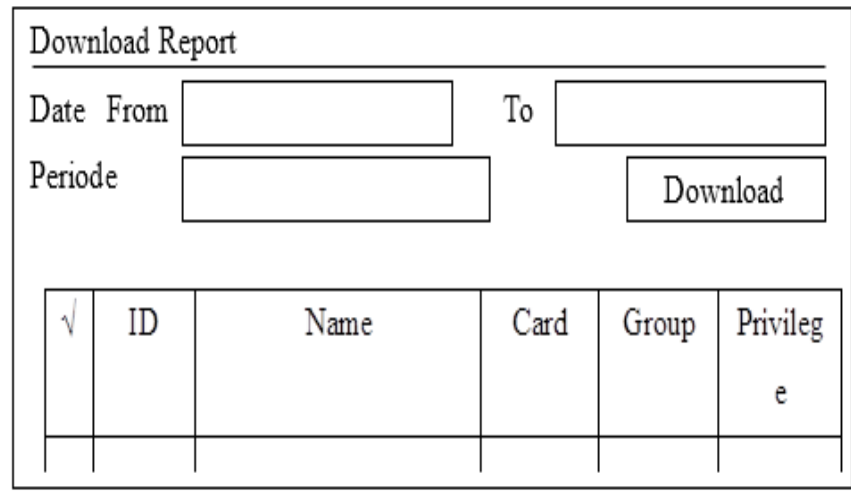

Gambar Desain interface cetak laporan

\section{KESIMPULAN DAN SARAN}

\section{Kesimpulan}

Sistem absensi di gunakan sebagai langkah awal dalam mendisiplinkan para pegawai yang dimulai dari kedisiplinan masuk kerja dan pulang kerja, dan dari penerapan sistem absensi diperoleh kesimpulan sebagai berikut : Solusi yang diberikan sistem absensi ini menghindari manipulasi kehadiran sebagai tolak ukur prestasi kedisiplinan pegawai, sehingga setiap diri pegawai akan mengejar prestasi kedisiplinan absensi dan akan menumbuhkan kedisiplinan kerja. Sistem informasi absensi berbasis sidik jari dapat mambantu pengolahan data kepegawaian di bagian kepegawaian dalam mengontrol kedisiplinan kerja pegawai.

\section{Saran}

Adapun saran yang dapat di ambil untuk kemajuan pada penelitian selanjutnya adalah sebagai berikut : data kehadiran pegawai setiap tiga bulan sebaiknya di evaluasi apakah terjadi peningkatan kedisiplinan pegawai tau tidak yaitu dengan analisis statistik yang dapat mengambil topik besarnya peranan sistem informasi absensi dengan sidik jari terhadap disiplin kerja pegawai. Perlu ditegakannya 
peraturan yang berlaku seperti teguran terhadap pegawai yang tidak masuk kerja atau pegawai yang terlambat apabila pegawai tersebut melanggar sebanyak tiga kali. Serta tindakan yang lebih lanjut hal ini dilakukan untuk meningkatkan disiplin kerja pegawai pada instansi tersebut, untuk lebih memudahkan karyawan dalam proses dokumentasi kehadiran,sebaiknya alat untuk pembacaan sidik jari yang saat ini digunakan yakniteknik "Sensor" diganti dengan teknik pembacaan yang berupa "Ultrasonik".Hal ini dikarenakan teknik pembacaan dengan ultrasonik tidak hanya mendeteksi permukaan atau tekstur sidik jari namun lebih detail sampai kedalam epidermal kulit, sehingga jari kering atau kulit mengelupas tidak terlalumenjadi masalah. Oleh karena itu tehnik ultrasonik dapat dikatakan lebih baik dibandingkan dengan teknik pembacaan sensor.

\section{DAFTAR PUSTAKA}

Apriyanto, I., MEANS UNTUK PENGELOMPOKAN KEYPOINT DESCRIPTOR.

Candra, R. \& Santi, N., 2008. Identifikasi Biometrik Sidik Jari dengan Metode Fraktal. , XIII(1), pp.6872.

E-voting, E. et al., 2013. Implementasi Fungsi Kriptografi dan Otentikasi Sidik Jari Pada Pemungutan Suara Berbasis. , 2(1), pp.1-5.

Karangayar, S.M.K.N., 2012. Analisis sistem presensi dengan sidik jari siswa smk negeri 2 karangayar. , 9(3), pp.27-32.

Leksono, B., Hidayatno, A. \& Isnanto, R.R., 2011. Aplikasi Metode Template Matching untuk Klasifikasi Sidik Jari. , 13(1), pp.1-6.

Ngantung, K.A. et al., 2014. Desain dan Implementasi Sistem Absensi Fingerprint di Jaringan Kampus dan Terintegrasi Dengan Sistem Informasi Terpadu UNSRAT.

Nurhantara, A., 2011. Sistem Informasi Presensi Menggunakan Sidik Jari ( Study Kasus Presensi Perkuliahan Program Studi Sistem Informasi FMIPA UAD ) Landasan Teori Penelitian Terdahulu. , 1(2), pp.137-150.

Rozikin, K. \& Purwantini, K., 2014. Pengaruh Sistem Presensi dengan Deteksi Sidik Jari dan SMS Gateway Terhadap Tingkat Membolos Siswa Gambar 1: Pola Sidik Jari. , 2014(November), pp.60-66.

Teknologi, E.D.A.N. et al., 2015. SUMBER DAYA UTAMA DAN TEKNOLOGI. , (2).

Tominanto, W.M., 2013. Sistem Informasi Berbasis Fingerprint untuk Meningkatkan Pelayanan Pendaftaran Pasien Rawat Jalan. INFOKES, 3 No.2.

Budi Raharjo, Imam Heryanto, Enjang RK, 2012, Pemrograman WEB, ISBN 978-602-8759-18-2, Modula.

Betha Sidik, Husni I Pohan, 2010, Pemrograman WEB dengan HTML, ISBN 978-602-8758-03-1, Informatika Bandung.

Muhamad Irsan, Rino Bayu Prasetyo Wibowo, Komputerisasi system presensi mahasiswa berbasis pemindahan sidik jari pada LP3I Cilegon, Prosiding seminar nasional industrial services (SNIS) III, Cilegon,8 Oktober 2013. 